\title{
Corn (Zea mays L.) seeding rate optimization in Iowa, USA
}

\author{
Mark A. Licht ${ }^{1} \cdot$ Andrew W. Lenssen ${ }^{1} \cdot$ Roger W. Elmore ${ }^{2}$
}

Published online: 8 August 2016

(C) The Author(s) 2016. This article is published with open access at Springerlink.com

\begin{abstract}
Collecting soil, topography, and yield information has become more feasible and reliable with advancements in precision technologies. Combined with the accessibility of precision technologies and services to farmers, there has been increased interest and ability to make site-specific crop management decisions. The objective of this research was to develop procedures to optimize corn seeding rates and maximize yield using soil and topographic parameters. Experimental treatments included five seeding rates (61 750; 74 100; 86 450; 98 800; and 111150 seeds ha $^{-1}$ ) in a randomized complete block design in three central Iowa fields from 2012 to 2014 (nine site-years). Soil samples were analyzed for available phosphorus (Olsen method), exchangeable potassium (ammonium-acetate method), $\mathrm{pH}$, soil organic matter (SOM), cation exchange capacity (CEC), and texture. Topographic data (in-field elevation, slope, aspect, and curvature) were determined from publically available light detection and ranging data. In four site-years, no interaction occurred between seeding rate and the descriptive variables. Three of the site-years resulted in a negative linear seeding rate response which made it impossible to determine an optimum seeding rate above the lowest seeding rate treatment. The seeding rate optimization process in five site-years resulted in seeding rate by variable interactions; four site-years had a single seeding rate by variable interaction $(\mathrm{pH}$, in-field elevation, or curvature) and one site-year had three seeding rate by variable interactions $(\mathrm{pH}, \mathrm{CEC}$, and SOM). Meaningful seeding rate optimizations occurred in only three of nine site-years. There was not a consistent descriptive variable interaction with seeding rate as a result of weather variability.
\end{abstract}

Reference to a product, trade or company name is for clarity only and does not imply approval or endorsement of the product, trade or company name by the authors or Iowa State University.

Mark A. Licht

lichtma@iastate.edu

1 Department of Agronomy, Iowa State University, 2104M Agronomy Hall, Ames, IA 50011, USA

2 Department of Agronomy and Horticulture, University of Nebraska, Lincoln, NE 68583, USA 
Keywords Corn $\cdot$ Variable rate $\cdot$ Seeding rate optimization $\cdot$ Topography $\cdot$ Soil properties

\section{Introduction}

Corn grain yields have increased since the 1930s in Iowa and across the U.S. Corn Belt. As corn grain yield increased, plant densities have also increased with a correlation of 0.65 (USDA-NASS 2015). Corn plant densities have increased by roughly 825 plants ha ${ }^{-1}$ year $^{-1}$ in Iowa since 2000 (USDA-NASS 2015). Currently, seeding rate recommendations that maximize yields for rainfed corn production in the central U.S. Corn Belt range from 69000 to 98800 seeds $^{-1}$ or more (Hoeft et al. 2000; Mueller and Sisson 2013; Nafziger 2012; Nielsen et al. 2015; Woli et al. 2014).

Corn yield exhibits a curvilinear response to increasing plant density where an optimal density can be determined. Up to the optimal plant density, the increase in total grain yield outweighs the reduction in yield per plant (Duncan 1984). After maximum yield is attained, competition for water, nutrients, and light become too great causing both field and per plant yields to decrease. Plant density yield response curves are influenced by biotic and abiotic factors (Shanahan et al. 2004; Van Roekel and Coulter 2011). Agronomists often assume that biotic yield-limiting factors such as incidence and severity of insects, weeds, and pathogens occur in-season and that these factors are minimized by management practices to as great an extent as possible in order to maximize yield. Abiotic factors that cause yield variability include topography as well as soil physical and chemical properties (Kaspar et al. 2004; Kravchenko and Bullock 2000; Kravchenko et al. 2003; Papiernik et al. 2005; Shanahan et al. 2004). The use of precision agriculture technologies offers the capability to better manage crop inputs and adjust for field variability associated with these abiotic factors.

Precision agriculture is based on the premise of using field information and advances in technology to manage crop requirements and agronomic practices in a site-specific manner to account for spatial and temporal variability (Bouma 1999; Hoeft et al. 2000; Mulla and Schepers 1997; Rawlins 1996; Searcy 1995). Early advances in precision agriculture included grid soil sampling, variable fertilizer applications, global positioning systems and yield mapping (Daberkow and McBride 1999; Mackay 1997; Taylor and Whelan 2010). Over the last two decades, variable rate seeding has developed from a concept to reality (Bullock et al. 1998; Clark and McGuckin 1996; Nafziger 2012). The advent of planter and monitor technology with the capability of planting at variable seeding rates across a field has given farmers and agronomists the ability to manage plant density using site-specific approaches to potentially increase productivity and profitability. Agronomists are now offering advice and services on variable rate seeding approaches.

Early in the adoption of variable rate seeding technology, Bullock et al. (1998) stated that for variable seeding to be profitable and productive, there needed to be a spatial relationship between yield and plant density as well as the influence of topographic and soil parameters on the relationship between grain yield and plant density. Therefore, these authors concluded that variable rate seeding would not be economically feasible at that time because of the difficulty in characterizing fields.

Initially site-specific, variable rate seeding determinations for corn were based on past yield productivity where higher yielding areas received higher seeding rates (Bullock et al. 1998; Butzen et al. 2012; Lowenberg-DeBoer 1999). However in Minnesota, Lamb et al. 
(1997) found that neither higher nor lower yielding field areas were consistent from year to year and that only 4-42\% of grain yield variability in a given year was accounted for by grain yield from previous years.

As variable rate seeding technology becomes more widely available and other precision technology improves, variable rate seeding is now often based not only on past yield productivity but also soil fertility, soil texture, SOM, landscape position, in-field elevation or some combination thereof (Butzen et al. 2012; Doerge 1999; Gunzenhauser and Shanahan 2011). Many of these factors relate to corn yield variability. Previously in Iowa, Kaspar et al. (2003) determined that higher landscape positions and steep slopes had lower yield potential than lower landscape positions in years with below average rainfall. Conversely, depressions and slight hillslopes had lower yield potential than landscape positions conducive to topographic drainage in years with above normal rainfall. These findings confirmed earlier work by Spitze et al. (1973) showing grain yields in northeast Nebraska were influenced by soil drainage and topography, with lowland poorly drained areas having higher yield potential than slopes and ridgetops.

The goals of this research were to (1) identify soil and topographic parameters that interact with seeding rate to influence corn grain yield and (2) determine potential soil and topographic parameters that can be used for site-specific optimization of corn seeding rates.

\section{Methods}

\section{Experimental design}

A field experiment was conducted over three growing seasons (2012-2014) and at three locations in central Iowa, USA to study corn response to seeding rate across landscapes. The fields were located in the Clarion-Nicollet-Webster soil association (Clarion [fineloamy, mixed, mesic, Typic Hapluduolls], Nicollet [fine-loamy, mixed, mesic, Aquic Hapluduolls], and Webster [fine-loam, mixed, mesic, Typic Endoaquolls]). The same three sites (Ames, $42^{\circ} 00^{\prime} 50.63^{\prime \prime} \mathrm{N},-093^{\circ} 44^{\prime} 24.81^{\prime \prime} \mathrm{W}$; Kelley, $41^{\circ} 57^{\prime} 09.27^{\prime \prime} \mathrm{N},-093^{\circ} 41^{\prime} 24.60^{\prime \prime} \mathrm{W}$; and Ogden, $42^{\circ} 00^{\prime} 21.55^{\prime \prime} \mathrm{N},-094^{\circ} 00^{\prime} 49.08^{\prime \prime} \mathrm{W}$ ) were used each of the three years of the experiment in a corn following corn rotation.

The experimental design at each site was a randomized complete block, with four replications at the Ames and Kelley sites and five replications at the Ogden site. Experimental treatments consisted of five seeding rates $(61750,74$ 100, 86450,98 800, and 111150 kernels $\mathrm{ha}^{-1}$ ). These seeding rates were chosen because they bracket the typical seeding rate of 82000 kernels ha $^{-1}$ used by farmers in Iowa. The plots were 16 rows wide at Ames and Kelley and 12 rows wide at Ogden by field length in a $0.762 \mathrm{~m}$ row spacing. Field length was approximately $400 \mathrm{~m}$ at Ames and Kelley and $720 \mathrm{~m}$ at Ogden.

All field operations were conducted by Iowa State University farm operations staff at the Ames and Kelley sites and the private farm operator at the Ogden site including fall and spring tillage, fertilizer applications, planting, herbicide applications and harvest. At all sites, a disk ripper was used for primary fall tillage and a full width field cultivator (Ames and Kelley) or a rotary harrow (Ogden) for secondary spring tillage. Planting and harvesting equipment was consistent across years (Table 1). Fields at all sites followed typical herbicide and soil fertility programs for phosphorus $(\mathrm{P})$, potassium $(\mathrm{K})$ and $\mathrm{pH}$ for the area (Mallarino et al. 2013). A target nitrogen (N) application of $224 \mathrm{~kg} \mathrm{ha}^{-1}$ was applied as a split application at Ames and Ogden and as single spring pre-plant application at Kelley. 


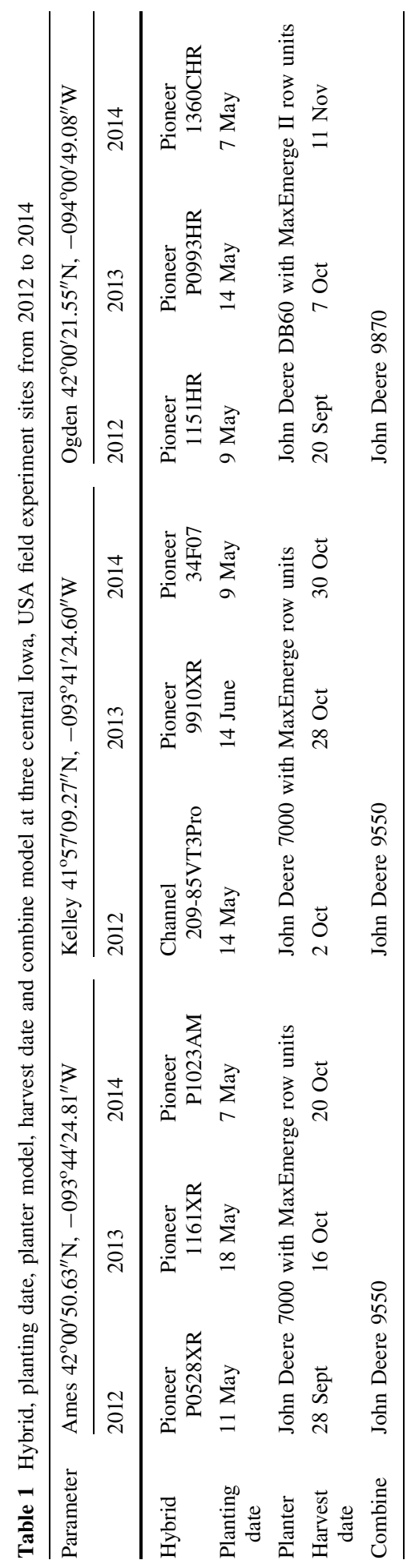


Different hybrids were planted each site-year resulting in the use of nine hybrids (Table 1). Climatic data was collected from Daymet Software version 2.0 (Thornton et al. 2015) for summation of monthly and growing season precipitation and accumulated growing degree days for each site-year and 30-year means for each site (Tables 2 and 3). Dayment software interpolates and extrapolates daily weather parameters using weather observations distributed by the National Climate Data Center and SNOTEL (SNOwpack and TELemetry) distributed by the Natural Resources Conservation Service, digital elevation models, algorithms, and computer software to produce $1 \mathrm{~km}$ square surface grids.

\section{Field data collection}

Sub-plots were established within each replicated seeding rate treatment $30 \mathrm{~m}$ apart. At Ames and Kelley, there were 11 sub-plots per strip and at Ogden there were 23 sub-plots per strip. A sub-plot consisted of the center two rows of each strip by $5.3 \mathrm{~m}$ long and was staked after planting. Sub-plots were located and marked using an Ashtech MobileMapper 100 (Sunnyvale, CA, USA) with a GNSS antenna that connected to the Iowa Real-Time Network for real-time kinematic global positioning at a 10-20 mm horizontal accuracy. Fourteen soil cores were taken to a depth of $150 \mathrm{~mm}$ at the sub-plot level and composite samples were collected between planting and the fourth leaf stage (Abendroth et al. 2011). Soil nutrient and texture analysis was conducted at Midwest Laboratories (Omaha, NE, USA) using standard laboratory procedures. Soil nutrient analysis included P, K, pH, SOM, and cation exchange capacity (CEC) (Dahnke 1975; Kalra 1997; Kuo 1996; Sumner and Miller 1996). The sodium bicarbonate method was used for P (Olsen et al. 1954) and the ammonium-acetate method was used for K (Helmke and Sparks 1996). Available water holding capacity (AWC) was calculated using soil texture and SOM based on Saxton and Rawls (2006).

\section{Grain yield and topographic spatial data}

Plots were harvested with combines equipped with calibrated yield monitors and GPS receivers to attain geo-referenced grain yield and moisture information. The harvest width was $9.1 \mathrm{~m}$ at Ames and Kelley, where logistically, the center $9.1 \mathrm{~m}$ of the $12.2 \mathrm{~m}$ seeding rate plot was harvested and the remainder of the plot (four outside rows) was used for collection of ear samples. At Ogden, the harvest width was $9.1 \mathrm{~m}$ and the entire plot width was harvested. Yield monitor data were processed and cleaned using Ag Leader Technology SMS Basic (Ames, IA, USA) to ensure start/stop delays, flow shifts, offsets, and erroneous points were omitted before exporting to ArcMap (ESRI 2014). ArcMap was used to determine yield and grain moisture at the sub-plot level by creating 6 or $4.6 \mathrm{~m}$ buffers around the central point of the sub-plot followed by a spatial join of the yield information. The buffer distance was half the plot width resulting in yield information for each sub-plot being an average of approximately five to seven yield monitor data points.

Topographic data were generated using $0.61 \mathrm{~m}$ contours from the LIDAR $3 \mathrm{~m}$ Digital Elevation Model of Boone and Story counties (IA, USA) available from the Natural Resources Geographic Information Systems Library of the Iowa Department of Natural Resources (https://programs.iowadnr.gov/nrgislibx/). ArcMap spatial analyst tools were used to determine in-field elevation, slope, curvature, and aspect of each sub-plot. In ArcMap, in addition to slope curvature, planar curvature (curvature perpendicular to the slope) and profile curvature (curvature parallel to the slope) can be determined (ESRI 2014). Positive curvature values result from convex slopes and negative curvature values 


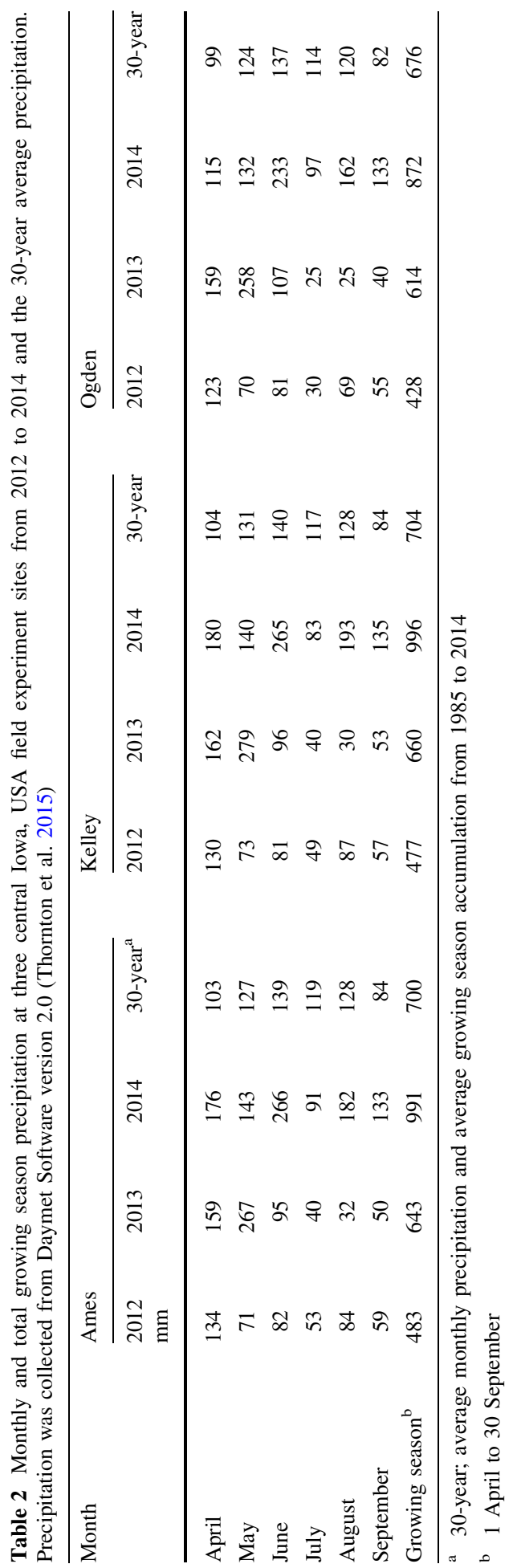




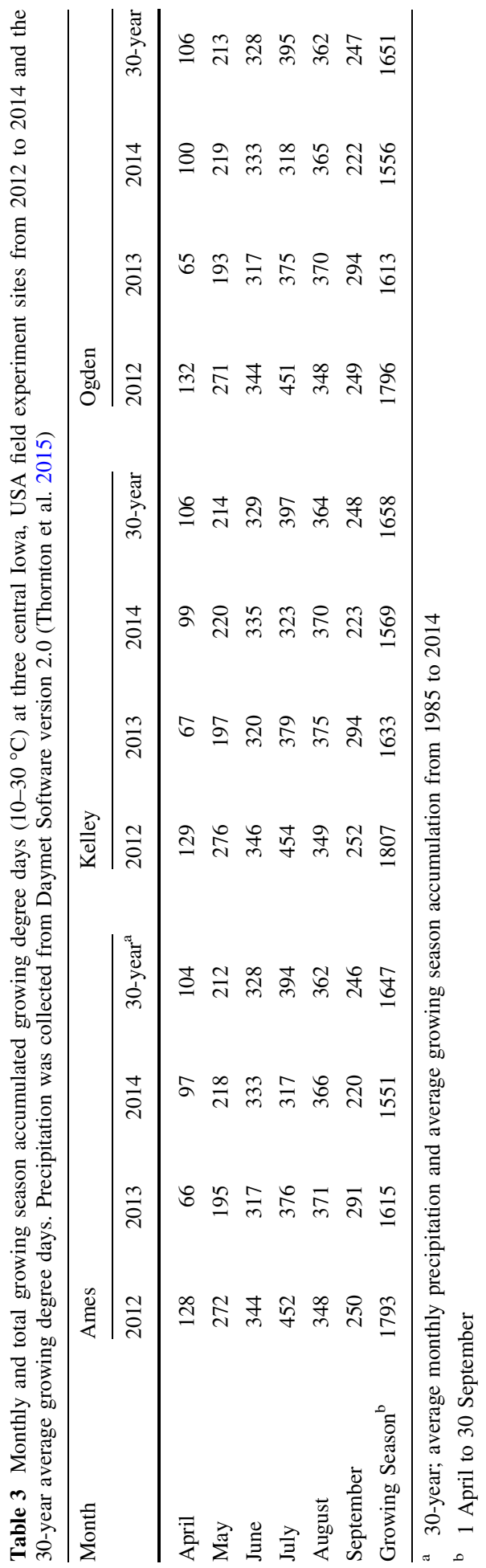


result from concave slopes. Slope aspect identifies the direction a slope faces (0 to 360 degrees). For this analysis, slope aspect was transformed to 'northness' with values of -1 to 1 where slope aspects of negative one are more south facing and slopes of positive one are more north facing.

\section{Statistical analysis}

Correlation and multiple regression analyses were conducted to understand and identify the key independent variables that best explained corn grain yield (SAS Instiute SAS Institute 2012). A stepwise regression procedure was used with $\alpha=0.05$ for variable addition and deletion in the final model prediction of grain yield. Independent variable collinearity in the regression model was identified using variance inflation factors (VIF). Where VIF of greater than 10.0 was identified, related independent variables were removed from the regression analysis. Collinearity existed between planar and profile curvature which resulted in the use of combined slope curvature. Silt and AWC were removed because collinearity existed between sand, silt, clay, SOM, and AWC. Even with exclusion of independent variables due to VIF greater than 10.0, P, K, SOM, and CEC had a VIF > 10.0 in one, two, four, and two site-years respectively. These variables were important and are common parameters used by farmers and agronomists and therefore retained within the regression and mixed model analysis.

The optimum seeding rate was estimated using a model where corn grain yield was the dependent variable. The initial model, included the effects of replication, seeding rate, seeding rate squared, identified soil and topographic parameters plus the seeding rate interaction with the soil and topographic parameters. A reduced model was then fit by excluding non-significant seeding rate interactions with soil and topographic variables. It was considered whether to include spatial dependence among residuals by fitting models with spatially correlated residuals. Gaussian and exponential covariance structures were computed from the X, Y coordinates of each sub-plot. The correlation between each pair of sub-plots depended on their Euclidean distance. None of the nine site-years showed evidence of spatial dependence in the residuals because the soil and topographic independent variables included in the mixed model accounted for the geographic dependence of the sub-plots.

Optimum seeding rates $\left(\mathrm{SR}_{\mathrm{opt}}\right)$ at each sub-plot were determined by solving the model for maximum seeding rate:

$$
\begin{gathered}
\text { Yield }=\beta_{0}+\beta_{1} S R+\beta_{2} S R^{2}+\beta_{3}(\operatorname{var} \times S R) \\
\text { Yield }=\beta_{0}+\left(\beta_{1}+\beta_{3} \text { var }\right) S R+\beta_{2} S R^{2}
\end{gathered}
$$

$\mathrm{SR}_{\max }$ solves Eq. 2

$$
\begin{gathered}
\frac{d \text { Yield }}{d S R}=\beta_{1}+\beta_{3} \text { var }+2 \beta_{2} S R_{\max }=0 \\
S R_{\text {opt }}=S R_{\max }=\frac{-\left(\beta_{1}+\beta_{3} \mathrm{var}\right)}{2 \beta_{2}}
\end{gathered}
$$

where Yield is the corn grain yield, SR is the seeding rate, var represents those soil attributes or topographic characteristics that interact with seeding rate, $\mathrm{SR}_{\max }$ is the seeding rate at which the highest yield can be expected, $S_{\mathrm{opt}}$ is the optimum seeding rate for the sub-plot based on the derivatives of corn grain yield, seeding rate, and significant seeding 
rate $\times$ variable interactions. The PROC MIXED procedure in SAS was used for the optimum seeding rate computations.

\section{Results and discussion}

\section{Field variability assessment}

Descriptive statistics revealed a significant amount of variability in soil properties and topographic characteristics across and within sites, with coefficient of variation (CV) values generally greater than $15 \%$ (Tables 4,5 ; Fig. 1). This amount of variability was desired for the purpose of the experiment and sites were selected based on perceived and known variability.

Mean grain yields across site-years were highly variable ranging from 10.4 to 12.7 $\mathrm{Mg} \mathrm{ha}^{-1}$ with $\mathrm{CV}$ values ranging from 5.3 to $33.2 \%$ (Table 4; Fig. 2). The greatest within-site corn yield variability was at Ames in 2013 which can be attributed to large variation in topographic characteristics combined with greater than normal precipitation following planting causing reductions in stand establishment in field depressions (results not shown). While the Kelley site in 2013 exhibited low corn grain yield variability, it too experienced greater than normal precipitation in April and May which resulted in a mid-

Table 4 Descriptive statistics of grain yield and selected soil nutrient parameters at three central Iowa, USA field experiment sites from 2012 to 2014

\begin{tabular}{|c|c|c|c|c|c|c|c|c|c|c|}
\hline \multirow[t]{2}{*}{ Parameter $^{\mathrm{a}}$} & \multirow[b]{2}{*}{ Year } & \multicolumn{3}{|l|}{ Ames } & \multicolumn{3}{|l|}{ Kelley } & \multicolumn{3}{|c|}{ Ogden } \\
\hline & & Mean & Range & $\begin{array}{l}\mathrm{CV} \\
(\%)\end{array}$ & Mean & Range & $\begin{array}{l}\mathrm{CV} \\
(\%)\end{array}$ & Mean & Range & $\begin{array}{l}\mathrm{CV} \\
(\%)\end{array}$ \\
\hline \multirow{3}{*}{$\begin{array}{l}\text { Grain yield, } \\
\mathrm{Mg} \mathrm{ha}^{-1}\end{array}$} & 2012 & 12.2 & $4.8-15.4$ & 12.6 & 11.3 & $5.8-13.7$ & 11.8 & 12.7 & $5.1-16.2$ & 13.9 \\
\hline & 2013 & 10.4 & $0.4-13.3$ & 33.2 & 10.7 & $6.4-12.3$ & 8.8 & 10.8 & $0.9-16.0$ & 17.4 \\
\hline & 2014 & 11.6 & $5.6-14.1$ & 12.0 & 11.0 & $2.1-13.8$ & 20.7 & 12.3 & $10.4-14.4$ & 5.3 \\
\hline \multirow[t]{3}{*}{$\mathrm{P}, \mathrm{mg} \mathrm{kg}^{-1}$} & 2012 & 11 & $6-18$ & 23.4 & 23 & $11-86$ & 52.6 & 15 & $5-72$ & 55.7 \\
\hline & 2013 & 12 & $5-47$ & 47.1 & 28 & $9-74$ & 42.4 & 17 & $5-81$ & 58.8 \\
\hline & 2014 & 14 & $4-66$ & 50.1 & 26 & $9-61$ & 37.4 & 19 & $5-68$ & 50.4 \\
\hline \multirow[t]{3}{*}{$\mathrm{K}, \mathrm{mg} \mathrm{kg}^{-1}$} & 2012 & 170 & $120-224$ & 15.9 & 224 & $176-412$ & 18.9 & 185 & $93-369$ & 29.4 \\
\hline & 2013 & 173 & 108-292 & 20.3 & 233 & 124-389 & 22.5 & 211 & 114-509 & 25.2 \\
\hline & 2014 & 166 & $85-281$ & 18.9 & 216 & $128-381$ & 20.6 & 196 & $85-470$ & 29.8 \\
\hline \multirow[t]{3}{*}{$\mathrm{pH}$} & 2012 & 6.5 & $5.3-7.9$ & 12.5 & 5.9 & $5.2-7.2$ & 7.7 & 7.0 & $4.6-8.1$ & 12.6 \\
\hline & 2013 & 6.2 & $4.7-8.1$ & 17.0 & 5.9 & $4.5-7.9$ & 14.0 & 6.8 & $4.6-8.1$ & 14.7 \\
\hline & 2014 & 6.2 & $4.6-8.1$ & 17.5 & 5.9 & $4.7-8$ & 14.5 & 6.7 & $4.5-8.1$ & 15.6 \\
\hline \multirow{3}{*}{$\begin{array}{l}\text { CEC, } \\
\mathrm{cmol} \mathrm{kg}^{-1}\end{array}$} & 2012 & 23.1 & $12.2-37.6$ & 31.5 & 24.9 & $15.8-33.3$ & 15.2 & 26.9 & $17.1-42.7$ & 20.3 \\
\hline & 2013 & 24.2 & $13.2-35.5$ & 25.6 & 24.9 & $14.3-35.6$ & 19.1 & 27.7 & $14.9-38.2$ & 18.3 \\
\hline & 2014 & 25.6 & $12.3-41.5$ & 27.1 & 26.2 & $13.8-38.7$ & 21.0 & 26.6 & $13.2-43.1$ & 21.6 \\
\hline \multirow[t]{3}{*}{$\mathrm{OM}, \mathrm{g} \mathrm{kg}^{-1}$} & 2012 & 40 & $14-68$ & 36.5 & 34.5 & $22-57$ & 18.0 & 42 & $24-86$ & 27.6 \\
\hline & 2013 & 39 & $11-69$ & 39.6 & 32.7 & $13-64$ & 25.7 & 44 & $21-86$ & 24.6 \\
\hline & 2014 & 45 & $15-78$ & 35.8 & 38.7 & $18-65$ & 21.8 & 47 & $22-95$ & 24.3 \\
\hline
\end{tabular}

a $P$ phosphorus, $K$ potassium, $C E C$ cation exchange capacity, $O M$ organic matter 


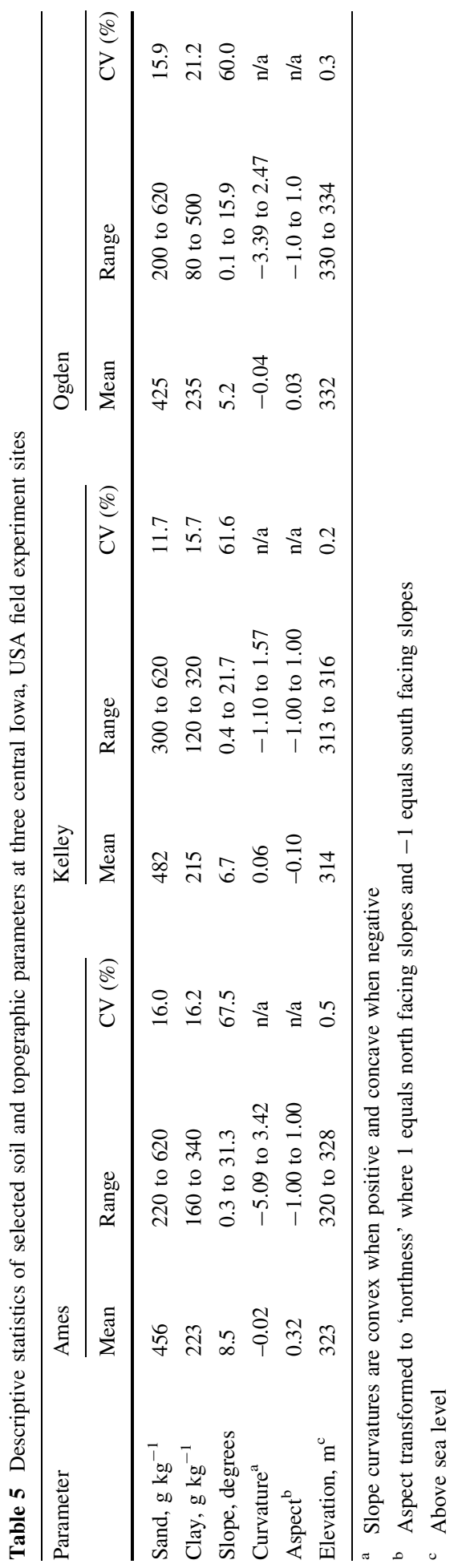



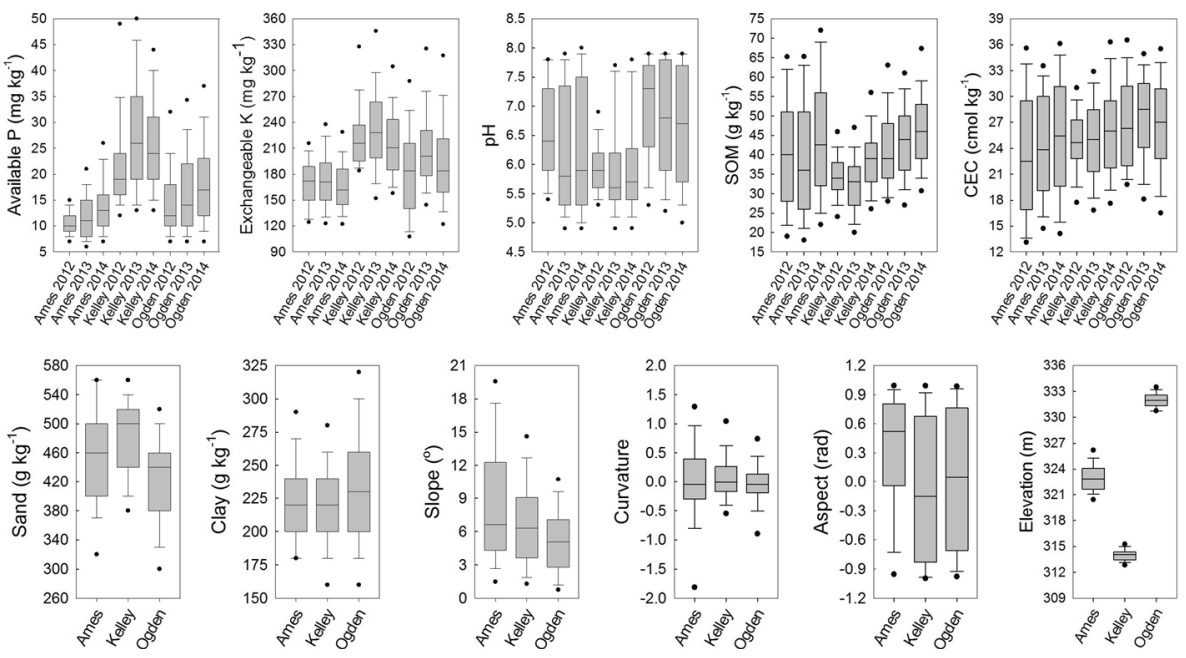

Fig. 1 Descriptive statistics of the soil variables and topographic characteristics of Ames, Kelley, and Ogden in central Iowa in 2012, 2013, and 2014. Median, line within the box; 25/75th percentile, box; 10/90th percentile, whiskers; 5/95th percentile, black dot

June planting date. Therefore, this site had less stand reduction due to saturated soil conditions than the other sites in 2013.

Corn yields were the highest in 2012 and the lowest in 2013 (Table 4). Kelley was the lower yielding site and Ogden was the higher yielding site. The annual corn yield variability can be attributed to climatic conditions: 2012 was extremely dry; 2013 was cool and wet in April and May, followed by dry conditions; and 2014 was cool and wet throughout the growing season (Tables 2, 3).

\section{Correlation and regression analysis}

Seeding rates and corn grain yield were correlated in seven of nine site-years. In six of these seven site-years, corn grain yields were negatively correlated with seeding rate (Table 6). Soil fertility parameters were inconsistently correlated with corn grain yields across site-years. In the abnormally dry year of 2012, slope, curvature and in-field elevation were negatively correlated with corn yield. Additionally, SOM and clay content were positively correlated with grain yield. In totality, the combination of these parameters suggest that water availability and storage are important parameters in determining yield potential and an optimal seeding rate for specific areas within fields, especially in years with dry weather conditions. Conversely, in 2013 and 2014, curvature and in-field elevation each were positively correlated with corn grain yield while clay and sand content were not consistently correlated with grain yield. Positive grain yield correlation with slope, curvature, and in-field elevation indicate that while the ability to capture and store water in a dry year is beneficial, in wet years a more variable topography results in water dispersion from the summit and hillslope landscape positions, and results in higher corn yields. The influence of soil water drainage and storage on grain yields have been well known but are highly inconsistent depending on soil type, topography, and climatic 


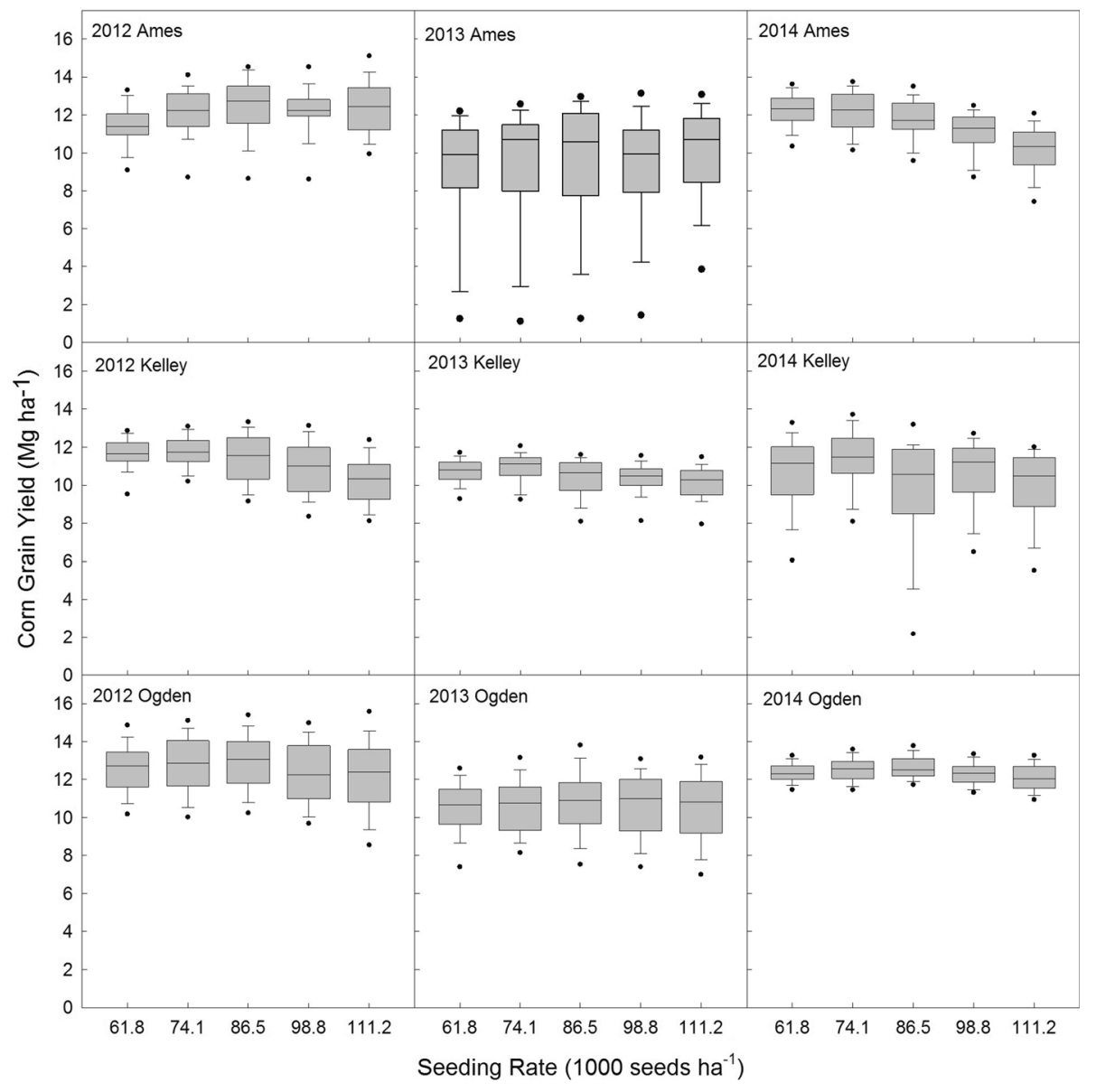

Fig. 2 Corn grain yield descriptive statistics by seeding rate for Ames, Kelley, and Ogden in 2012 to 2014. Median, line within the box; 25/75th percentile, box; 10/90th percentile, whiskers; 5/95th percentile, black $d o t$

conditions of the research sites (Kaspar et al. 2004; Kravchenko and Bullock 2000; Runge and Hons 1999; Spitze et al. 1973).

Generally, the step-wise regression models reflect the correlation coefficients for each site-year (Table 7). The highest coefficients of determination $\left(\mathrm{R}^{2}\right)$ for the regression model analysis were at the Ames site with an $\mathrm{R}^{2}$ of 0.65 and 0.77 in 2012 and 2014 respectively. The lowest $\mathrm{R}^{2}$ values were at Kelley in 2013, Ogden in 2012, and Ames in 2013, $\mathrm{R}^{2}=0.16,0.17$, and 0.20 respectively. Regression analysis included seeding rate and/or seeding rate squared in all site-years except Ames in 2013. In most situations, the seeding rate and seeding rate squared parameters were negative and extremely low, indicating little influence of seeding rate on the yield prediction.

In both Ames and Kelley, the regression model $\mathrm{R}^{2}$ values were much lower in 2013 compared to 2012 and 2014 . These lower $R^{2}$ values can be attributed to areas of the field that had reduced plant densities and yield due to saturated soil conditions early in the year 


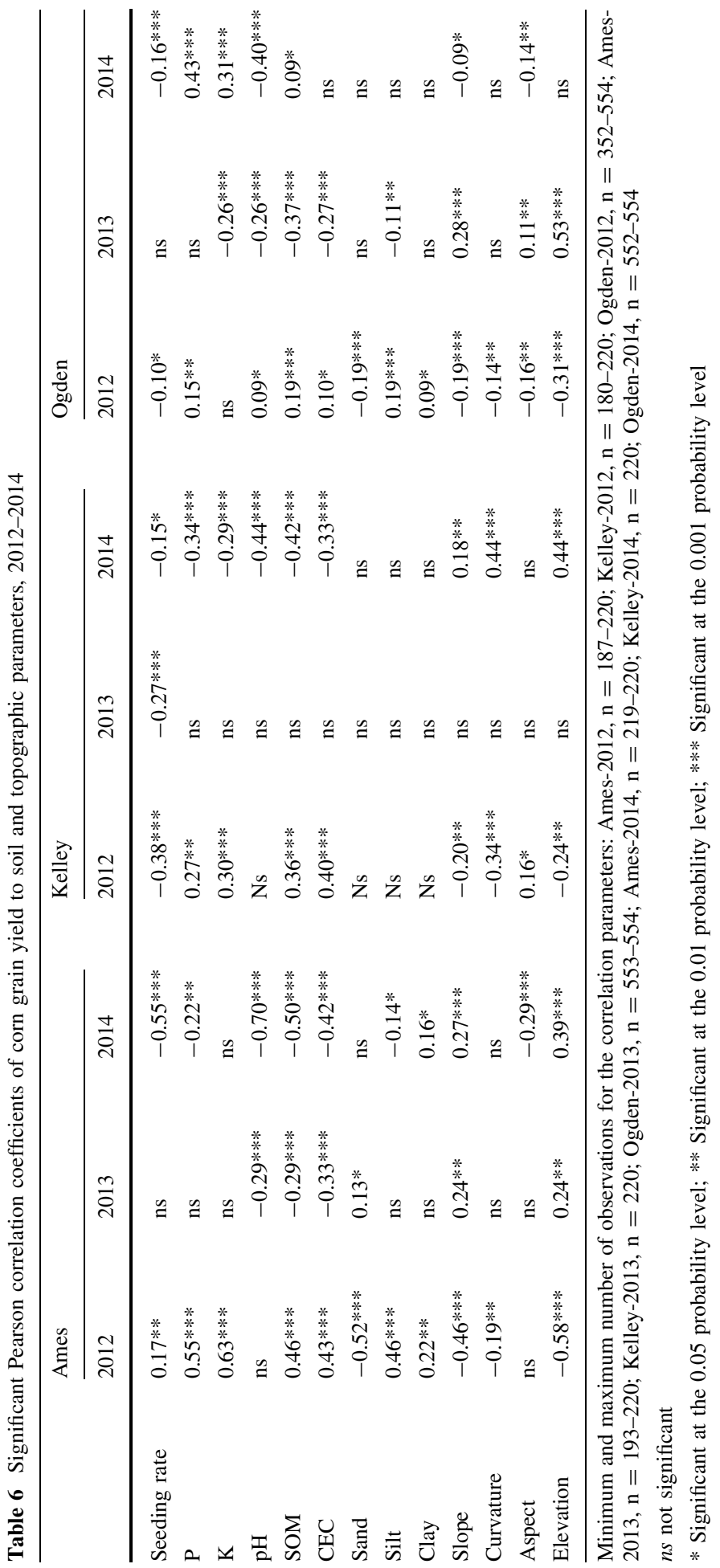




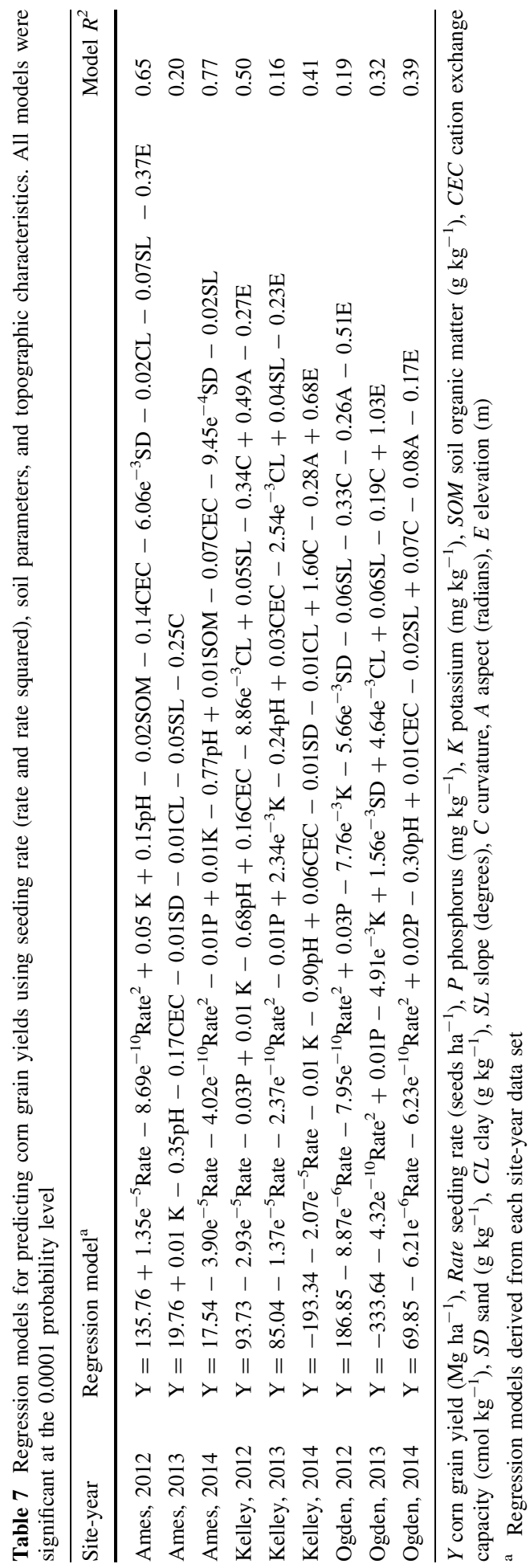




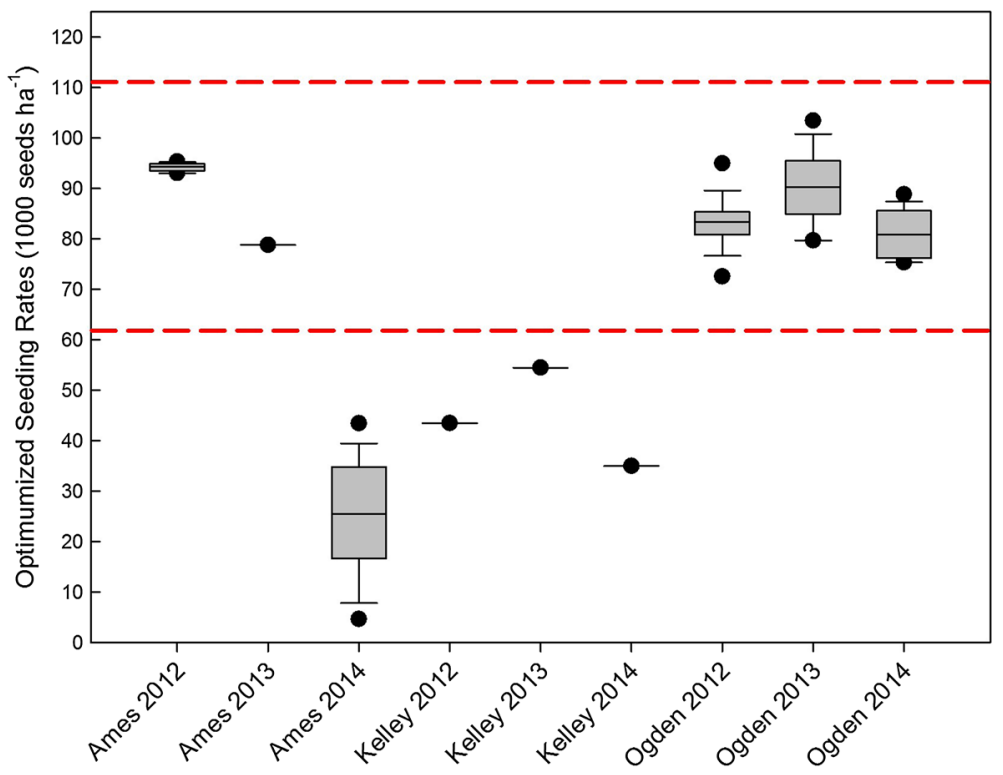

Fig. 3 Range of optimized seeding rates for each sub-plot of each site-year from central Iowa. Median, line within the box; 25/75th percentile, box; 10/90th percentile, whiskers; 5/95th percentile, black dot; dashed line indicates upper and lower seeding rate treatment used

and dry conditions that were detrimental to grain production during grain fill later in the season. Therefore, most of the parameter coefficients in the regression model were low and therefore had little effect on the yield prediction.

\section{Seeding rate optimization}

The focus of this work was to determine if there is a way to use known field characteristics combined with seeding rate treatments and yield outcomes to determine optimum seeding rates for future plantings based on those known field characteristics. The results showed that in four site-years (Ames 2013 and Kelley 2012, 2013, and 2014) there was no optimized seeding rate due to a lack of a seeding rate interactions with soil parameters and topographic characteristics (Fig. 3). This does not mean soil parameters or topographic characteristics do not influence corn grain yields. It does mean that the optimization of seeding rates was not affected by the selected field characteristics.

Five site-years had a seeding rate interaction with a soil parameter(s) and/or topographic characteristic(s). Of the five site-years, Ames 2014 had optimum seeding rates below the range of corn seeding rate treatments used in the experiment, thus limiting the validity and usefulness of the seeding rate optimization analysis for this site-year. This is very likely due to low coefficient estimates for seeding rate interactions with $\mathrm{pH}, \mathrm{CEC}$, and SOM combined with essentially no coefficient estimate for seeding rate squared $\left(-2.84 \mathrm{e}^{-10}\right)$. In Ames in 2014, the seeding rate response curve across the field had a narrow range of peak yields between the 61750 and 74100 seeds $^{-1}$ seeding rates.

Four site-years (Ames 2012 and Ogden 2012, 2013, 2014) provided corn seeding rate optimizations that fell within the range of seeding rate treatments used in the experiment, 


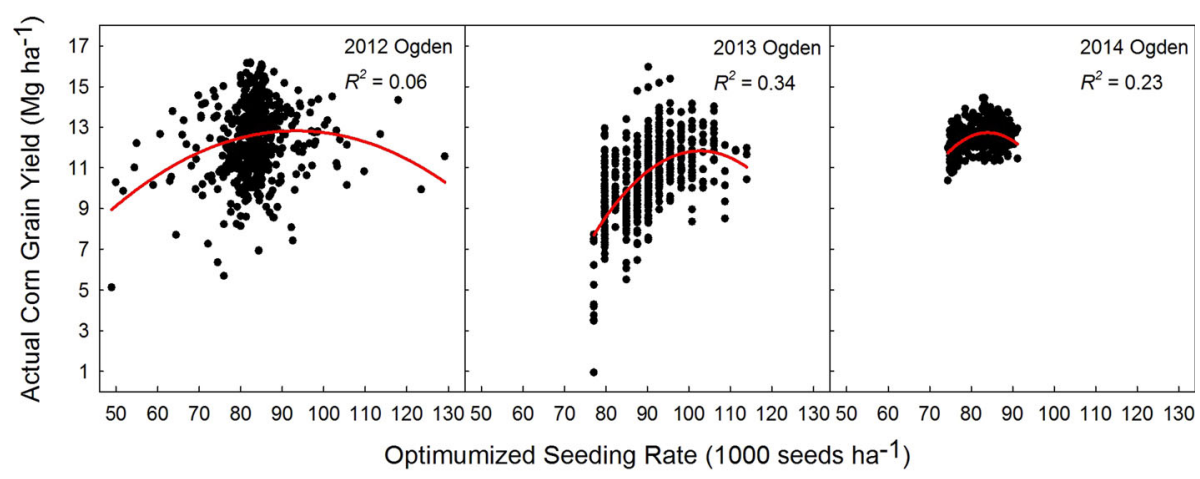

Fig. 4 Corn grain yield at the optimized seeding rate for each sub-plot for Ogden in 2012-2014

three of which provided a range of optimum seeding rates large enough to develop a dynamic seeding rate response curve (Fig. 4). The Ames 2012 optimum seeding rates ranged from 92950 to 95430 seeds ha $^{-1}$ while the Ogden site had mean optimum seeding rates of 83270,90680 , and 81020 seeds $\mathrm{ha}^{-1}$ in 2012, 2013, and 2014, respectively. The Ogden site-year seeding rate response curves match up to seeding rate response curves used as the basis for corn seeding rate recommendations that maximize yields (Hoeft et al. 2000; Mueller and Sisson 2013; Nafziger 2012; Nielsen et al. 2015; Woli et al. 2014).

\section{Conclusions}

The site years of this study proved not only to have large variability of soil and topographic parameters but also considerable corn grain yield and optimum seeding rate variability. Individual sites exhibited different corn yield and seeding rate responses due in part to differences in field variability. Slope, curvature, in-field elevation, and SOM were commonly correlated with corn yield in dry climatic conditions of 2012. When the planting and growing season had normal to cool/wet conditions, corn yield correlations to variables were less consistent. Regression models for all site-years were inconsistent in the amount of yield variability accounted for by the soil and topographic variables (16-77\%).

When seeding rate optimization was performed, only three of nine site-years resulted in meaningful seeding rate response curves that warranted use of variable seeding rates across fields. Even in those site-years, there was considerable variation of the optimization model. These findings support the hypothesis that for variable rate seeding to be viable there is a need for seeding rate to be influenced by soil attributes and topographic characteristics with an additional need for consistency of seeding rate interaction with soil attributes and topographic characteristics from year to year and field to field.

Determining a single optimum seeding rate methodology based on soil and/or topographic variables across a farming operation seems unlikely due to seeding rate response and interactions with variability of climatic conditions and field characteristics. Based on this study, further research needs to be conducted to better understand how seeding rate optimization can be accomplished effectively. Development of seeding rate response curves for individual management zones based on indices that account for the influence of 
soil fertility, water holding capacity, and landscape position on seeding rate response curves would be of great value.

Acknowledgments The authors express appreciation to Rod and Brett Pierce and the Committee for Agricultural Development for their cooperation and use of farm land as well as DuPont Pioneer for seed corn donations in 2013 and 2014. The Agricultural Experiment Station Consulting Group helped with statistical approaches, especially Dr. P. Dixon and I. Alvarez-Castro.

Open Access This article is distributed under the terms of the Creative Commons Attribution 4.0 International License (http://creativecommons.org/licenses/by/4.0/), which permits unrestricted use, distribution, and reproduction in any medium, provided you give appropriate credit to the original author(s) and the source, provide a link to the Creative Commons license, and indicate if changes were made.

\section{References}

Abendroth, L. J., Elmore, R. W., Boyer, M. J., \& Marlay, S. K. (2011). Corn growth and development. PMR 1009. Ames: Iowa State University Extension.

Bouma, J. (1999). Precision agriculture: a unique tool to unify production and environmental requirements in agriculture. In P. C. Robert, R. H. Rust, \& W. E. Larson (Eds.), Precision agriculture (pp. 595-601). Madison: ASA/CSSA/SSSA.

Bullock, D. G., Bullock, D. S., Nafziger, E. D., Doerge, T. A., Paszkiewicz, S. R., Carter, P. R., et al. (1998). Does variable rate seeding of corn pay? Agronomy Journal, 90(6), 830-836.

Butzen, S., Gunzenhauser, B., \& Shanahan, J. (2012). Putting variable-rate seeding to work on your farm. Johnston: DuPont Pioneer.

Clark, R. L., \& McGuckin, R. L. (1996). Variable rate application technology: An overview. In P. C. Robert, R. H. Rust, \& W. E. Larson (Eds.), Precision Agriculture (pp. 855-862). Madison: ASA/CSSA/SSSA.

Daberkow, S. G., \& McBride, W. D. (1999). Adoption of precision agriculture technologies by U.S. Corn producers. In P. C. Robert, R. H. Rust, \& W. E. Larson (Eds.), Precision agriculture (pp. 1821-1831). Madison: ASA/CSSA/SSSA.

Dahnke, W. (1975). Recommended chemical soil test procedures for the north central region. Number 499 (revised). Fargo: North Dakota State University.

Doerge, T. (1999). Site-specific management guidelines: management zone concepts. SSMG-2. Norcross.

Duncan, W. G. (1984). A theory to explain the relationship between corn population and grain yield. Crop Science, 24(6), 1141-1145.

ESRI (2014). Arcgis 10.2.2. ArcMap (10.2.2.3552 Ed.). Redlands: ESRI (Environmental Systems Resource Institute).

Gunzenhauser, B., \& Shanahan, J. (2011). Using multi-year yield analysis to create management zones for variable rate seeding. Johnston: DuPont Pioneer.

Helmke, P. A., \& Sparks, D. L. (1996). Lithium, sodium, potassium, rubidium, and cesium. In D. L. Sparks, A. L. Page, P. A. Helmke, \& R. H. Loeppert (Eds.), Methods of soil analysis Part 3-chemical methods (Vol. 5.3, pp. 551-574). Madison: SSSA/ASA. SSSA book series.

Hoeft, R. G., Nafziger, E. D., Johnson, R. R., \& Aldrich, S. R. (2000). Modern corn and soybean production (1st ed.). Champaign: MCSP Publications.

Kalra, Y. (1997). Handbook of reference methods for plant analysis. Boca Raton: CRC Press.

Kaspar, T. C., Colvin, T. S., Jaynes, D. B., Karlen, D. L., James, D. E., \& Meek, D. W. (2003). Relationship between six years of corn yields and terrain attributes. Precision Agriculture, 4(1), 87-101.

Kaspar, T. C., Pulido, D. J., Fenton, T. E., Colvin, T. S., Karlen, D. L., Jaynes, D. B., et al. (2004). Relationship of corn and soybean yield to soil and terrain properties. Agronomy Journal, 96(3), 700-709.

Kravchenko, A. N., \& Bullock, D. G. (2000). Correlation of corn and soybean grain yield with topography and soil properties. Agronomy Journal, 92(1), 75-83.

Kravchenko, A. N., Thelen, K. D., Bullock, D. G., \& Miller, N. R. (2003). Relationship among crop grain yield, topography, and soil electrical conductivity studied with cross-correlograms. Agronomy Journal, 95(5), 1132-1139.

Kuo, S. (1996). Phosphorus. In D. L. Sparks, A. L. Page, P. A. Helmke, \& R. H. Loeppert (Eds.), Methods of soil analysis Part 3-chemical methods (Vol. 5.3, pp. 869-919). Madison: SSSA/ASA. SSSA book series. 
Lamb, J. A., Dowdy, R. H., Anderson, J. L., \& Rehm, G. W. (1997). Spatial and temporal stability of corn grain yields. Journal of Production Agriculture, 10(3), 410-414.

Lowenberg-DeBoer, J. (1999). Economics of variable rate planting for corn. In P. C. Robert, R. H. Rust, \& W. E. Larson (Eds.), Precision agriculture (pp. 1643-1651). Madison: ASA/CSSA/SSSA.

Mackay, D. (1997). Precision farming: connecting the pieces. In D. A. Lobb (Ed.), Precision Farming: Challenges and Opportunities for Atlantic Canada. Charlottetown.

Mallarino, A. P., Sawyer, J. E., \& Barnhart, S. K. (2013). A general guide for crop nutrient and limestone recommendations in Iowa. PM 1688. Ames: Iowa State University Extension.

Mueller, D., \& Sisson, A. (2013). Corn field guide. Ames: Iowa State University Extension and Outreach.

Mulla, D. J., \& Schepers, J. S. (1997). Key processes and properties for site-specific soil and crop management. In F. J. Pierce \& E. J. Sadler (Eds.), The state of site-specific management for agriculture (pp. 1-18). Madison: ASA/CSSA/SSSA.

Nafziger, E. D. (2012). Corn in Illinois agronomy handbook. Champagne-Urbana: University of Illinois Extension and Outreach.

Nielsen, R., Lee, J., Camberato, J. (2015). Yield response to plant population for corn in Indiana. Purdue University. http://www.agry.purdue.edu/ext/corn/news/timeless/SeedingRateGuidelines.html. Accessed 16 July 2016.

Olsen, S., Cole, C., Watanabe, F., \& Dean, L. (1954). Estimation of available phosphorus in soil by extraction with sodium bicarbonate. USDA Circular 939. Washington DC: United States Department of Agriculture.

Papiernik, S. K., Lindstrom, M. J., Schumacher, J. A., Farenhorst, A., Stephens, K. D., Schumacher, T. E., et al. (2005). Variation in soil properties and crop yield across an eroded prairie landscape. Journal of Soil and Water Conservation, 60(6), 388-395.

Rawlins, S. L. (1996). Moving from precision to prescription farming: the next plateau. In P. C. Robert, R. H. Rust, \& W. E. Larson (Eds.), Precision Agriculture (pp. 283-294). Madison: ASA/CSSA/SSSA.

Runge, E. C. A., \& Hons, F. M. (1999). Precision agriculture: development of a hierarchy of variables influencing crop yields. In P. C. Robert, R. H. Rust, \& W. E. Larson (Eds.), Precision agriculture (pp. 143-158). Madison: ASA/CSSA/SSSA.

SAS Institute. (2012). The SAS system for Windows. Release 9.3. Cary: SAS Institute.

Saxton, K., \& Rawls, W. (2006). Soil water characteristic estimates by texture and organic matter for hydraulic solutions. Soil Science Society of America Journal, 70(5), 1569-1578.

Searcy, S. W. (1995). Engineering systems for site-specific management: opportunies and limitations. In P. C. Robert, R. H. Rust, \& W. E. Larson (Eds.), Proceedings of the 2nd International Conference on site specific management for agricultural systems (pp. 595-604). Madison: ASA/CSSA/SSSA.

Shanahan, J. F., Doerge, T. A., Johnson, J. J., \& Vigil, M. F. (2004). Feasibility of site specific management of corn hybirds and plant densities in the great plains. Precision Agriculture, 5(3), 207-225.

Spitze, D. C., Rehm, G. W., \& Moomaw, R. S. (1973). An effective educational approach for working with adult farmers. Journal of Agronomic Education, 2, 36-39.

Sumner, M. E., \& Miller, W. P. (1996). Cation exchange capacity and exchange coefficients. In D. L. Sparks, A. L. Page, P. A. Helmke, \& R. H. Loeppert (Eds.), Methods of soil analysis Part 3chemical methods (Vol. 5.3, pp. 1201-1229). Madison: SSSA/ASA. SSSA book series.

Taylor, J., Whelan, B. (2010). A general introduction to precision agriculture. Grains Research and Development Corporation. http://www.agriprecisione.it/wp-content/uploads/2010/11/general_ introduction_to_precision_agriculture.pdf. Accessed 16 July 2016.

Thornton, P., Thornton, M., Mayer, B., Wilhelmi, N., Wei, Y., Devarakonda, R., et al. (2015). Daymet: daily surface weather data on a 1-km grid for North America; Version 2. Oak Ridge: Oak Ridge National Laboratory Distributed Arctive Archive Center. http://daac.ornl.gov.

USDA-NASS. (2015). Crop production 2014 summary. Washington DC: United States Department of Agriculture, National Agricultural Statistics Service.

Van Roekel, R. J., \& Coulter, J. A. (2011). Agronomic responses of corn to planting date and plant density. Agronomy Journal, 103(5), 1414-1422.

Woli, K. P., Burras, C. L., Abendroth, L. J., \& Elmore, R. W. (2014). Optimizing corn seeding rates using a field's corn suitability rating. Agronomy Journal, 106(4), 1523-1532. 